\title{
SOME ASPECTS OF SUSTAINABILITY AND SYNERGY IN THE EMERGING TEACHER TRAINING
}

\author{
Inta Ratniece \\ Riga Teacher Training and Educational Management Academy (RPIVA),
}

\begin{abstract}
The emerging English as a foreign language teachers develop their professional competence better if they participate in global informal studies by collaboration involving global synergy issues, which develop higher their professional competence. Analysis of theoretical sources and empirical research. Results of global informal studies organized by 12 higher education teacher training institutions analyzed. Global learning shared in master classes, lectures, case studies in Austrian schools, text books for learning English compared. Lessons conducted by international teams on global learning analyzed. Results disclosing the reactions of the participants included. Valid knowledge on teaching English and sustainability gained. Synergy brings valuable knowledge needed for professional competence development on teaching/learning.
\end{abstract}

Key words: development education, sustainability, equity, global synergy, teacher training.

\section{Introduction}

"In the decade up to 2020 European higher education has a vital contribution to make in realising a Europe of knowledge that is highly creative and innovative. Europe can only succeed in this endeavour if it maximises the talents and capacities of all its citizens and fully engages in lifelong learning as well as in widening participation in higher education" (Ministers responsible for Higher Education in the countries participating in the Bologna Process, Leuven/Louvain-la-Neuve Communiqué, April 2009).

Both emerging English as a Foreign Language (EFL) teachers and their teacher trainers develop their competence more professionally if they participate in global collaboration projects involving global teaching/learning issues, which develop their professional competence in synergy environment. Results of CiTiFoLa project IP by twelve higher education teacher training institutions on ESD and active citizenship should be reflected on to understand global learning/teaching discussed in master classes, lectures, case studies better. Lessons conducted by international teams on global learning, sustainable development (SD) and equity need to be reflected on to develop competence further. For competence increase the findings and results provide valid knowledge, as well as synergy skills gained by the teacher trainees and the academic staffs. Lesson planning and conducting experience developed lead to a new strategy promoting global learning (ESD, SD and equity) to be suggested and conclusion is obvious - collaboration brings along professional competence development on teaching/learning of English as a foreign language by inclusion of global learning in synergy environment. 
The aim of study is to reflect on and analyse competence development due to the emerging EFL teacher collaboration in informal studies in global intergenerational synergy stimulation environment.

Research methods used for the study are theoretical literature research on development education, social constructivism and human pedagogy, competence development, mentoring in the process of teaching/learning stimulating synergy as the source for the emerging teachers and teacher trainers' development and empirical method implementation by collection of data and analysis of the participants' self-reflections, reflection in peer groups with promotion teacher trainers and the teacher trainer's reflection following the collected participants' self-assessment materials (consisting of Self-assessment 1 and 2).

\section{Materials and methods}

"Development education is about investing in people here in the European Union - children and adults alike - who have invested in us so that, in return, we can assist them in becoming truly global citizens in a globalized world. And in turn, through their actions and engagement, we will be investing further in our fellow human beings in the developing world still striving to pull themselves out of poverty" (EC Commissioner Andris Piebalgs at the Hearing on Development education, European Parliament, Brussels, 2011).

Development education, social constructivism and human pedagogy perceive each learner as a "unique individual with unique needs and backgrounds. The learner is also seen as complex and multidimensional" (Inman, Buck, 1995; Wertsch, 1998; Žogla, 2001; Holt, Willard-Holt, 2000; Smith, 2003; McEvoy , Hayton, Wrnick, Mumford, Hanks, Blahna, 2005; Tilıla, 2005; Špona, 2006).

Development education encourages pursuing the global dimension incorporating the "key concepts of global citizenship, conflict resolution, diversity, human rights, interdependence, social justice, sustainable development and values and perceptions, interconnections between the local and the global" (Bartram, 2005). It builds self-experience, knowledge, skills and understanding, as well as developed skills, attitudes, competencies and lead to increased competence.

Nowadays researchers discuss also the significance of mentoring in the process of teaching/learning (Inman, Buck, 1995; Žogla, 2001; Smith, 2003; Špona, 2006; Ratniece, 2009). The social constructivists, as well as human pedagogy representatives, thus maximize the significance of the correlation between the learner and the teacher trainer or teacher in the teaching/learning process.

Millennium Goals advocates continue that reality is created by our own actions, activities (Holt, Willard-Holt, 2000; Žogla, 2001; Hopkins\&McKeown, 2002; Smith, 2003; Bartram, 2005; McEvoy, Hayton, Wrnick, Mumford, Hanks, Blahna, 2005; Tillaa, 2005; Špona, 2008; Wells, 2010). 


\section{Findings and Results}

Both analysis of the project achievements and reflections on the results compiled prove that the emerging teachers had been increasingly made to realise that we live in a globalised and interconnected world and that learning needs to play a major role in helping us all to find our place and move forward to sustainability promotion. The informal studies consisting of theoretical and practical tasks allowed to acquire better personal learning strategies alongside with ideas how to transform the gained knowledge, skills and competencies due to diversified and increased competence for teaching of the other generation learners in global environment.

The project also pointed out the need for synergy, in direct contradiction to traditional competitive approaches. Teaching and learning within a group or team context can be particularly effective in higher education. This synergy atmosphere imitates potential workplace that students would expect to find after graduation. The skills learned such as the ability to listen and learn from their peers, is essential in many vocations. The emerging EFL teachers and their teacher trainers have found that this peer-to-peer cooperative learning and teaching atmosphere resulted in students questioning and being involved at a higher-level. If students have to present and train new contents with their peers for transferring them to young learners, a non-linear process of collective knowledge-construction is set up. Problem solving has become their main teaching method. The emphasis is on students' understanding and improving through the process of synergy and mediation. The trainee teacher becomes more proficient, the lecturers as well start using less traditional assessment and increasingly introduce based on competence assessment and self-assessment. The students and the lecturers plan the activities cooperatively in international teams by mediating and collaborating (Ratniece, 2009).

As we can see from the diagram in Picture 1 the trainee teachers after collaborating in the Intensive Programme (IP) - informal studies in global synergy environment had considerably increased their professional competence as English as a foreign language teachers. This was established not only due to the second self-assessment (Group 1- successful applicants to IP; Group 2 Control group), but also by correlation with the experts' evaluation of the both groups' success in their school practice and qualification examination that took place after the IP participants had have the global informal studies.

The emerging EFL teachers had self-assessed themselves (Group 1- successful applicants to IP, target group; Group 2 - control group) before the entering the Intensive Programme CiTiFoLa of the EquiTiFoLa project, which was developed, organized and carried out by twelve teacher training higher education institutions from twelve states in and beyond the European Union. Level A - low, level C - high. Both groups at this stage have the same Level A in education for sustainable development, and respectively $\mathrm{B}$ and $\mathrm{C}$ in functional 
English as a foreign language as learners and as emerging teachers. It is clearly seen that both groups on average have similar percentage in Level A - (Group $1-32 \%$ and Group 2 - 32\%) and Level B (Group 1 - 58\% and Group 2 - 66\%), a slight difference is witnessed in Level $\mathrm{C}$ before the Intensive Programme (Group $1-11 \%$ and Group $2-2 \%$ ). Then the IP participants were involved into developing their knowledge, skills, competencies, attitudes of functional foreign language learning and education for sustainable development in informal studies as high priority issues for the transferring their competence when conducting the lessons for the young learners in global environment. They used the same model highlighting collaboration in training, after teaching again at the end of the Intensive Programme to reflect and self-assess their growth. It clearly revealed a major increase of Level C in Group 1 (knowledge, skills, competencies, attitudes in total leading to promoted competence) from $2 \%$ before the Intensive Programme to $89 \%$ after the IP. The control group, which did not have the opportunity to participate in global informal studies, has retained the same average levels.

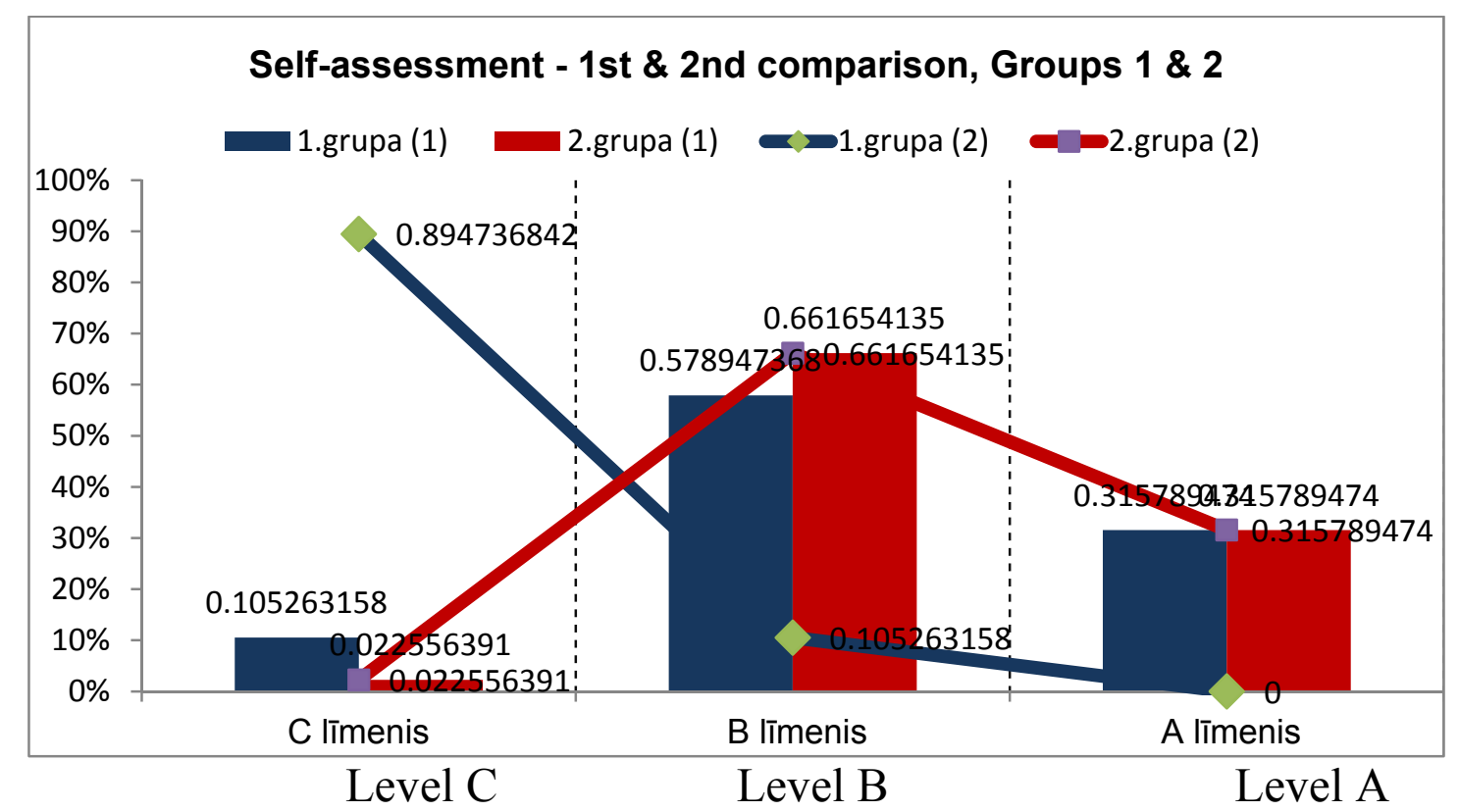

Picture 1 Average assessment of the control group in comparison with the average assessment of the IP participants' target group

In the framework of the pedagogical practice the emerging teachers (Control group 2) got the lesson designing rolling, directed it, and focused it in the Intensive programme and in their native environment. The emerging teachers IP participants (Target group 1) acted as a part of separate international teams consisting of four members in global environment cooperatively to make it work. They all participated, but not in a competitive way. Rather, they all shared in the responsibility and the targets, much as any members share in any team sport. Their targets were the same: to get insight into the subject, to clarify the subject, to untangle its mysteries, to interpret and share and learn from other 
points of view, to piece together the jigsaw puzzle using everyone's contribution. Discussion and discourse skills proved to be important. Everyone had to be aware of how to get the discussion rolling and keep it rolling and exciting. Also in English as a foreign language, a number of skills are necessary in global teaching/learning to work on and use at appropriate times; everyone is expected to contribute by using these skills.

Furthermore, it was argued during the reflections that the responsibility of learning should reside increasingly with the learner. The emerging teachers thus emphasized the importance of the learner being actively involved in the learning process, unlike previous educational viewpoints where the responsibility rested with the instructor to teach and where the learner played a passive, receptive role. All members of Intensive Programme emphasized that learners constructed their own understanding and that they did not simply mirror and reflect what they had read. Learners looked for meaning and tried to find regularity and order in the events of the world even in the absence of full or complete information.

In their group reflections the IP participants from Group 1 insisted that the student value experience, opportunity to equal global collaboration both with peers and representatives from other generations for cognition of innovative ideas, views that usher in positive changes, alternative interpretations of sustainable development. The attained innovative self-experience in global environment lead to increase of competence for their future socio-pedagogical collaboration pursuing successful professional career.

The reflections show that for major innovations modernizing the formal studies by informal studies inclusion a project like the discussed should be accessible to more students. At present in case of successful project designing by the twelve pedagogical teacher training institutions, only 3 - 4 emerging teachers from each institution can participate in the Intensive Programme.

The research results have led to concusions that the above mentioned (the associations in reflections and presentations after IP, the opinions of experts) mostly refer only to one part of the problem - the theoretical content of the subject. Development of the synergy stimulated socio-pedagogical competence as a process, steadily increasing education level, updating the unity of knowledge, skills, competencies and attitudes, mutual correlation have not been analysed enough as causes, reasons or results for possible radical alternatives yet (See Picture 2).

Picture 2 reveals schematically grouped the emerging teacher actions and collaboration in informal studies in global intergenerational synergy environment leading to Updated learning self-experience that initiates a new higher development cycle of Creative Self-cognition and cognition by synergy, namely, a higher developed professional socio-pedagogical competence of the emerging teacher. 


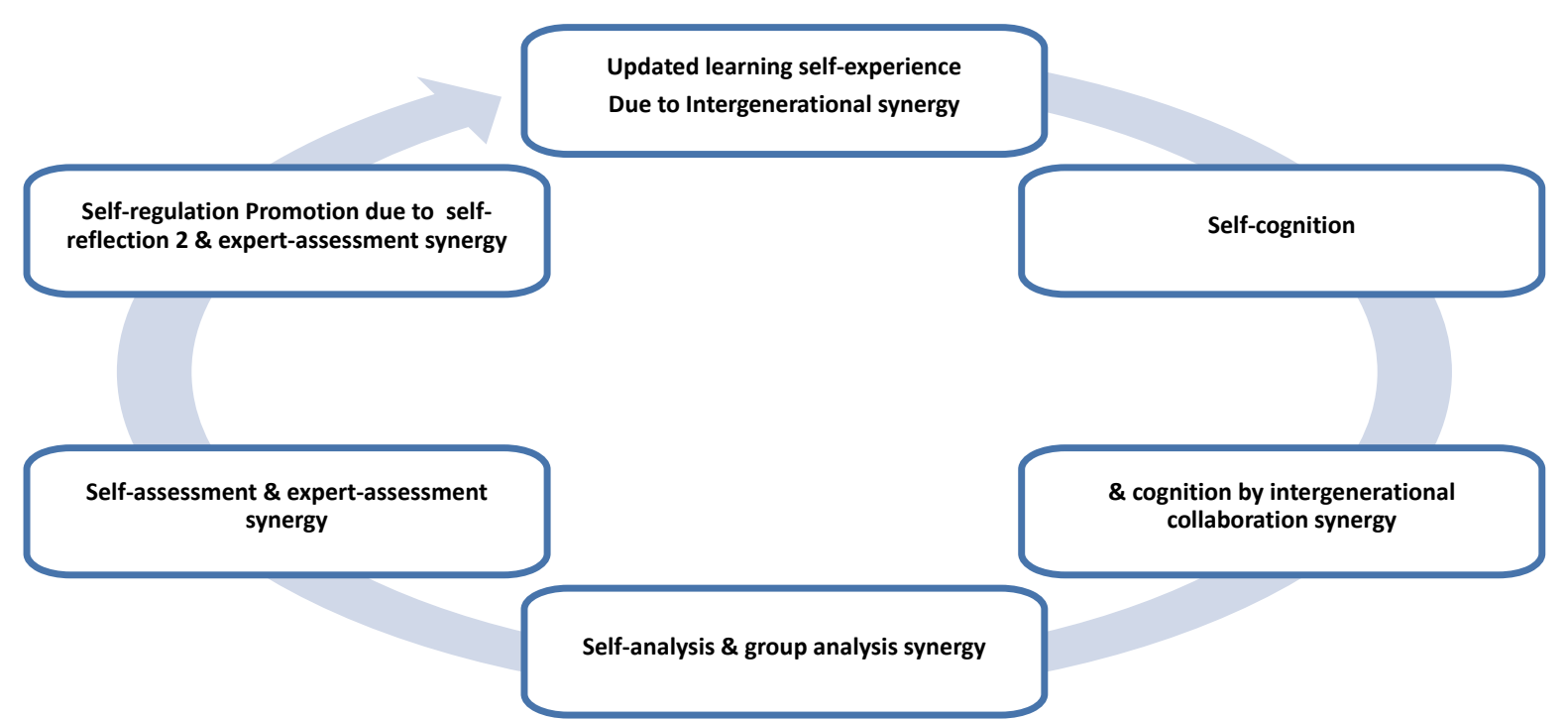

Picture 2 Synergy stimulated competence development due to the emerging EFL teacher collaboration in informal studies in global intergenerational synergy environment

Synergy stimulated competence development due to the intergenerational synergy environment as socio-pedagogical action phenomenon, respectively, involves creative self-cognition and cognition by collaboration, self-analysis and group analysis, self-reflection and group reflection, self-assessment and assessment by others, self-regulated development, actualized learning/teaching experience, which produce secondary self-experience gained through interaction and collaboration in global Intensive Programme, generating a new cognition collaboration cycle. The above mentioned is involved in the ring of sustainable development global environment. Especial meaning is provided by the enclosed arrow, which determines impact and development directions of continuous determined action. It shows the emerging teacher opportunities. Communication and collaboration skills directly influence the creative cognitive mediation collaboration, self-analysis directly shapes the group analysis, self-reflection directly shapes the group reflection, self-assessment correlates with assessment by others, and self-regulated development in correlation actualizes teaching/learning experience and vice versa, as the cycle is not terminated, yet synergy increase the development opportunities benevolently. By the emerging EFL teacher entering collaboration at any stage of the creative cycle shaped by the arrow, the correlation can be experienced - the cognitive action stimulates creative collaboration, creative action due to synergy itself is collaboration directed. The secondary self-experience does not exist in parallel with the primary self-experience, it is innovative, developed self-experience due to intergenerational synergy - an introduction to sustainable development. By socio-pedagogical action, mediation and collaboration results' synergy creates updated values, unites traditions, ideas, definitely sustainable development ideas, their acquisition, maintenance, protection, ability to 
appreciate them, include them into personal value scale and use purposefully. The next cycle brings along improvements as there is created upgraded motivation turning the emerging teacher into a creative positive society transformer and updates the socio-pedagogical performance level. By this correlation link of action and collaboration emerges promoted personal development due to intergenerational synergy serving as the trainee teacher's creative competence sustainability upgrading professional life content.

\section{Conclusions}

Through the process of synergy in learning the emerging English as a Foreign Language teacher becomes more proficient, the lecturers as well start using less traditional assessment and increasingly introduce based on competence selfassessment and assessment more widely. Integration of language and social issues provides a motivational and cognitive basis for language learning since it is interesting and of great value to the emerging teacher striving to become a part of global citizenship ideas' promotion. Language is learnt most efficiently for teaching young learners by informal studies communicating meaningful, purposeful, social (sustainable development, global citizenship ideas' promotion) and academic content by participation in projects and their Intensive Programmes. Collaborative learning methods can improve the effectiveness of student learning/teaching in content-integrated interactive classroom, in the intervening time in the foreign-language classes the quantity and quality of student talk can be increased by involving issues on sustainable development and global citizenship. The synergy skills that students learn apparently transfer. Cooperatively learning students are more likely than other students to use the cooperative behaviours they had been taught when they perform as teachers during their pedagogical practice involving sustainable development, global citizenship issues and ICT based projects. Students who learn in synergy environment tend to be more highly motivated to learn and transfer sustainability ideas because of increased self-esteem, the pro-academic attitudes of team, appropriate attitudes to success and failure, and more determined ontask behaviour. They also score higher on tests of achievement and problem solving. They tend to get along better with students and colleagues of different racial, ethnic, and social class backgrounds. The results show that language courses which are provided by higher education institutions are too short and need more credits and time to promote sustainable development and global citizenship ideas by mediating socio-cultural cognition topics with functional foreign language training.

\section{References}

1. Bartram, D. (2005). The Great Eight competencies: A criterion-centric approach to validation. Journal of Applied Psychology, 90, 1185-1203. 
2. Holt, D. G. \& Willard-Holt, C. (2000). "Let's get real - students solving authentic corporate problems". Phi Delta Kappan 82. Retrieved 14/08/2010, from http://en.wikipedia.org/wiki/Constructivism

3. Hopkins, C. \& McKeown, R. (2002). Education for sustainable development: an international perspective. In Education and sustainability: Responding to. Retrieved 17/10/2011, from ibcperu.org/doc/isis/13028.pdf

4. Inman, S. \& Buck, M. (1995). 'Adding Value', Stoke on Trent, Trentham Books Inman, $\mathrm{S}$ et al, 'Assessing Personal and Social Development

http://arrts.gtcni.org.uk/gtcni/bitstream/2428/11522/1/ATL\%20Schools\%20Councils.pdf.

5. Liepa, D. \& Ratniece I. (2011). Collaboration with students in reorientation teacher training to education for sustainable development and global citizenship. UK Teacher education network for Education for sustainable Development/Global Citizenship. Building capacity for ESD/GC in times of change. 2011 Conference Proceedings. ISBN 978-0-946786-72-5, pp.106- 119.

6. McEvoy, G., Hayton, J., Wrnick, A., Mumford, T., Hanks, S., \& Blahna, M. (2005). A competency-based model for developing human resource professionals. Journal of Management Education, 29, 383- 402.

7. Ministers responsible for Higher Education in the countries participating in the Bologna Process, Leuven/Louvain-la-Neuve Communiqué, April (2009). Retrieved on 14/10/2011/ from http://www.ond.vlaanderen.be/hogeronderwijs/bologna.

8. Piebalgs, A. (2011). Speech by commissioner Andris Piebalgs at the Hearing on Development Education. European Parliament, Brussels, 30 August 2011, p.7 Retrieved 17/01/2012, https://webgate.ec.europa.eu/.../Speech_EP_Hearing_non_formated.p.

9. Ratniece, I. (2009). Development of professional competence and collaboration skills in ERASMUS project framework. Proceedings of the international scientific conference: Society. Integration. Education. ISBN 978-9984-44-018-7; Rezekne: RA, 2009. pp.184191./in Latvian/.

10. Roger, A. (2004). Looking again at formal and informal education - towards a new paradigm. Retrieved 14/08/2010, from The encyclopaedia of informal education: www.infed.org/biblio/non_formal_paradigm.htm

11. Smith, M. K. (2003). 'Learning theory', the encyclopedia of informal education. Retrieved 14/08/2010, from www.infed.org/biblio/b-learn.htm

12. Špona, A. (2006). Audzināšanas process teorijā un praksēe. Rīga: RaKA, 211 lpp.

13. Špona, A. (2008). Socio-pedagogical problems of modern students' attitude towards school. Signum Temporis. Pedagogy \& psychology. Vol.1, No1, March, 2008, pp.10 - 17.

14. Tiḷıa, I. (2005). Sociālkultūras mācīšanās organizācijas sistēma. Rīga: RaKa, 295 lpp.

15. Wells, G. (2010). Schooling: the contested bridge between individual and society. Pedagogies: An International Journal, 5: 37-48.

16. Wertsch, J. V. (1998). Mind as action. Oxford University Press, pp. 203, ISBN 019 511753

17. Žogla, I. (2001). Didaktikas teorētiskie pamati. Rīga: RaKa, 275 lpp.

$\begin{array}{ll}\text { Mag.philol., Mag.paed. } & \text { RPIVA, Pedagogijas fakultāte, Vispārējās pedagogijas un } \\ \text { Inta Ratniece } & \text { valodu katedra } \\ & \text { Imantas 7.līnija 1, Rīga, LV1083, Latvija } \\ & \text { E-mail: inta.ratniece@rpiva.lv; } \\ & \text { tel.+371 26588658 }\end{array}$

